\title{
7 Over Hills and Valleys Too
}

\author{
China's Belt and Road Initiative in the Caribbean
}

Ruben Gonzalez-Vicente

\begin{abstract}
Chapter 7 focuses on the Caribbean, specifically on Jamaica and Trinidad and Tobago. Taking these two states as cases, it shows how the BRI's financial muscle and infrastructural building capacity have transformed the Caribbean developmental landscape. Key to this transformation has been China's capacity to launch new projects in heavily indebted or cash-strapped economies. It has resulted in some of the region's traditional 'partners', such as the IMF or the European Union, losing their undisputed capacity for influence and coercion. However, Sino-Caribbean relations have also helped entrench long-established structural and postcolonial impediments for development. The chapter argues the BRI represents another iteration of neoliberal business-centric development in the region and so does not produce qualitative socio-economic change.
\end{abstract}

Keywords: Belt and Road Initiative, China, agency, Caribbean, Jamaica, Trinidad and Tobago

Few regions in the world can claim relations with China that are as multifaceted and complex as those currently held by the Caribbean. Despite its small population of just about 46 million inhabitants, scattered around sixteen sovereign states and seventeen dependent territories, the Caribbean contains not only exporters of natural resources, economies with a manufacturing base, and world-class tourism destinations, but also a mix of high-, mid- and low-income economies. It is also home to five states that do not officially recognize the People's Republic of China (PRC); one of the few remaining communist regimes in the world; and the two major destinations for Chinese investment in the world, if we exclude Hong Kong,

Schneider, Florian (ed.), Global Perspectives on China's Belt and Road Initiative: Asserting Agency through Regional Connectivity. Amsterdam, Amsterdam University Press 2021 DOI: 10.5117/9789463727853_CHO7 
the British Virgin Islands and the Cayman Islands. ${ }^{1}$ Consequently, the region occupies a curious position in relation to China's Belt and Road Initiative $(\mathrm{BRI})^{2}$ : commercially, it is an almost insignificant periphery, albeit one full of infrastructural investment opportunities following decades of economic impasse; financially, it is at the core of many crucial operations, channelling Chinese investments and guarding the fortunes of Chinese elites; geopolitically, it is an area of logistical importance due its proximity to the Panama Canal, and is also a potential minefield right at the centre of the unilaterally designated 'backyard' of the United States; diplomatically, it represents China's last frontier in the battle with Taiwan over international recognition.

In this chapter, I will focus on China's relations with the fourteen sovereign states that are members of the Caribbean Community (CARICOM). I choose this focus because the diversity of relations would make it too complex to cover all of the Caribbean within one cohesive in-depth analysis. From this vantage point, the chapter argues that the BRI has significantly shifted the hierarchies of development in the Caribbean, but it has done so without necessarily altering the region's broad developmental trajectory. In particular, the BRI has allowed regional economies to triangulate beyond a few traditional Western 'partners' (a generous word in this context) in search of better financing deals. However, despite broadening the developmental landscape, the BRI has also contributed to a narrow developmental horizon. The BRI's infrastructural focus has done little to reverse the region's structural dependence on the world market, the unequal postcolonial socio-economic order within Caribbean societies, or the prevalence of neoliberal business-centric understandings of development among local political elites. Whereas these are issues that can be attributed to the historical preconditions and contemporary political agency within the region, BRI projects have helped to perpetuate these trends by discouraging transparent, accountable, and participatory development approaches. This chapter also contends that the failure of the BRI projects to broadly improve socio-economic conditions in the Caribbean has resulted in an increased backlash from a wide range of social actors in precisely those countries where the BRI has been most successful in advancing Chinese business interests.

1 Forty per cent of all the assets managed in the British Virgin Islands are traceable to Chinese and Hong Kong capital, including rerouted investments of state-owned enterprises and offshore dealings by Chinese top officials and business elites (Donovan 2018; Robertson 2019).

2 Rather than studying the BRI as an institutional initiative that requires countries to become formal signatories, I refer to the BRI more flexibly as a political economic stage in China's developmental trajectory characterized by the internationalization of the country's construction sector in response to issues of domestic overaccumulation. 
This chapter draws on fieldwork conducted over a period of more than five years in nine Caribbean countries, Taiwan, and the PRC. During this time, I conducted 83 interviews on China-Caribbean relations, held meetings with a number of local stakeholders, participated in regional fora, and collaborated with colleagues at the University of the West Indies to track and analyse China's variegated engagements in the region. The chapter is organized as follows. The first section briefly reviews the history of (under) development in the Caribbean to contextualize contemporary Chinese activities in the region. The second section provides a panoramic view of the different Chinese economic activities in the Caribbean, giving particular attention to the different stages of engagement, the relevant actors, and the preponderant types of investment driving the relationship. After this, the next two sections explore BRI activities in two countries: Jamaica, and Trinidad and Tobago. A conclusion then summarizes the chapter's findings and core arguments.

\section{Antecedents: A Drama in Three Acts}

The developmental outcomes and geopolitical repercussions of BRI activities in the Caribbean cannot be properly assessed without considering the context in which they take place. A proper understanding of the Caribbean context needs to assess the repercussions of the colonial, neocolonial/ dependent, and neoliberal periods that are found within the region's contemporary social configuration and international links.

These processes can be traced back to the incorporation of the Caribbean into the European colonial system in the fifteenth century. They found particular salience in the eighteenth century, when European empires crafted a system of international production centred around Caribbean sugar. For Eric Williams, Caribbean plantation economies represented the first instance of globalization in the modern world, comprising slave labour brutally uprooted from Africa, European finance capital, trans-Atlantic trade routes, along with Caribbean production and European consumption (Williams 1984). Going far beyond the trade relations that different parts of the world had previously held, this complex commercial apparatus represented the world's first attempt at globalized production. For the Caribbean, this resulted in a process of 'passive incorporation' into the world economy as plantation societies. This 'passive incorporation' would have fundamental repercussions for the Caribbean both in terms of its outward relations with the rest of the world and its domestic social configurations (Girvan 2009). It 
would be impossible to review here all the different ways in which colonial history has shaped the postcolonial trajectory of Caribbean societies, but it would also be misguided to ignore the many living legacies from the colonial past. Amongst these legacies, three should at least be mentioned briefly. The first is how Caribbean sugar economies remained largely monocultural, dependent on external markets, and very vulnerable to external economic fluctuations following formal decolonization (Gumbs 1981). The second is how a sort of 'epistemic dependency' developed in relation to the imperial powers that had designed and managed the colonies from afar (Beckford 1972). The third is the way in which domestic societies were, and in some cases still are, stratified following racial patterns (Bissessar \& La Guerre 2013).

Many of these features survived in more or less similar forms into the post-independence period. Indeed, critical scholars from the region and post-independence leaders clearly identified many of the impediments to development that had prevailed during the colonial years (GonzalezVicente \& Montoute 2020). However, the various attempts to break away from structural and epistemic dependency encountered formidable opposition and were short-lived. The result was a perpetuation of said dependency into the post- or neocolonial period. In general, many newly independent states experimented with import-substitution strategies in the 1960 ond 1970s (ECLAC 2000). Some of these countries, such as Barbados, Jamaica, and Trinidad and Tobago, developed a manufacturing base but were overall unable to truly substitute imports. Perhaps more radically, other countries, such as Jamaica, Guyana, and Grenada, experimented with indigenous forms of socialism. These experiments either ended up becoming something different (as in the case of Guyana's economic nationalism under Forbes Burnham) or were crushed by the pressures of transnational investors or direct military invasion by the United States (as in Grenada in 1983) (Stone 1986). The oil crisis of 1973 also affected the finances of many oilimporting countries in the region. Meanwhile the debt crisis of the early 1980 s decimated the entire region, pushing many governments into the hands of the International Monetary Fund (IMF).

It was therefore in the late 1970 s and early 1980 s that the neoliberal era began in the Caribbean. Jamaica, for example, signed its first two agreements with the IMF in 1977 and 1978 . This initiated a profound restructuring of the Jamaican economy in the 1980 s, which included currency devaluation, reduced government expenditure, and liberalization of prices and imports (Lundy 1999). While the IMF was initially able to force the region into a market-oriented trajectory (Kirton \& Ferguson 1992), increasingly the 
unfolding of neoliberalism would also rely on compliant regional leaders who saw no 'viable alternatives' to the new market consensus (Levitt 2009: 192). This is curious, as the switch to neoliberal orthodoxy was not able to reduce the levels of indebtedness in most countries in the region, which instead soared and would soon top world rankings of debt relative to GDP despite the close attention these countries had paid to IMF guidance (ECLAC 2018). Jamaica, for example, had repaid more than it had ever lent by 2013 , but high interest rates kept the country among the most heavily indebted in the world. By 2009, interest costs consumed as much as $50 \%$ of Jamaican tax revenues, while this figure has remained at around $30 \%$ since then (Clarke 2019). As a result, Jamaica's budgets for education, healthcare and poverty eradication shrank (Dearden 2013). In general terms, discontent with IMF conditionalities and their impacts has continued to grow throughout the Caribbean (Black 2001). Yet the region has also been increasingly tied by debts and policy commitments that have effectively meant that the economic plans of many countries in the region have been actively drafted and supervised by international finance institutions (Girvan 2012). Today, the economies of the region stand out for their high degrees of openness, dependence on a few export-oriented natural resources sectors and tourism, and reliance on foreign markets. This, on the whole, renders the region particularly vulnerable to exogenous economic shocks. It has also reduced the region's international negotiating capacity as a block, despite the efforts of the Caribbean Community, which remains marred by a minimalist intergovernmental approach and a broad neoliberal allegiance (Payne \& Sutton 2007; Grenade 2011).

All of this means that the Caribbean that China encounters in the twentyfirst century is one that in terms of external links remains structurally vulnerable to external shocks and is dependent on foreign markets. It is one where epistemic dependency is still apparent in the way in which regional economic policies are devised by Washington, DC-based institutions. Many countries in the region have attained middle-income status or above, often on account of enclave sectors such as tourism and natural-resource extraction. However, this status actually runs counter to their possibilities of accessing bilateral and multilateral development grants. Internally, the inability to develop economically has resulted in high levels of inequality, poverty, and vulnerability, with high unemployment rates also leading to a worrying rise of violence throughout the region (Pantin 1996; CDB 2016). The Caribbean is therefore a region that after decades of neoliberal orthodoxy seems ready to engage new partners willing to entertain unorthodox economic alternatives. 


\section{The China Connection: A New Stage?}

The relationship between China and the English-speaking Caribbean can be traced to 1806, when a vessel of the East India Company arrived in Trinidad with 192 Chinese immigrants brought to complement the then waning influx of African slave labour (Look Lai 1998: 22). The arrival of indentured Chinese workers would intensify following the abolition of chattel slavery in the British West Indies in the 1830 s. As the Asian community grew, many of its members went on to play important roles in the development of the region throughout the twentieth century. Notable examples in high politics include Solomon Hochoy, the first Governor-General of Trinidad and Tobago; Arthur Chung, the first President of Guyana; and Eugene Chen, a Trinidadian lawyer who would befriend Sun Yat-sen to later become the foreign minister of the Republic of China. Beyond politics, Chinese descendants also left an imprint in Caribbean culture. Jamaican-Chinese producers like Vincent Chin and Leslie Kong helped to popularize reggae music, while artists like Edwin Ayoung succeeded as prominent calypsonians in Trinidad and Tobago. However, the links covered in this chapter are more recent and relate to the internationalization of Chinese capital since the start of the new millennium.

Just like many other regions in the developing world, the Caribbean started experiencing the rise of China in an indirect way. Through the $1990 \mathrm{~s}$ and the first decade of the twenty-first century, global value chains started to re-centre around China, attracted first by an almost unlimited pool of inexpensive labour, but also gradually by the country's logistical capacity and increasingly qualified workforce. This dealt a death blow to those Caribbean economies that still aspired to develop a manufacturing base with the possible exception of the Dominican Republic. Competition from China became insurmountable, particularly following its ascension to the World Trade Organization in 2001 (Bernal 2000; Padilla Pérez \& Hernández 2010). In parallel, China's industrialization and its relentless urbanization process, the largest in world history, would increase the demand for natural resources and subsequently raise their prices, which facilitated a decade of economic growth in countries that export natural resources during the resource boom of 2003-2013. These two trends combined and pushed the Caribbean region to further retrench to its comparative advantages in a number of natural resources sectors and the tourism industry - two of the only niches in which it could remain globally competitive in a world economy that increasingly tilted towards China.

However, it was the arrival of Chinese capital in the Caribbean that first signalled an epochal change in the eyes of many observers. Chronologically, 
we can distinguish three periods of Chinese investment and financial activity in the Caribbean. The first period, running up until 2007, involved limited activity, most of which was in relation to the PRC's battle for diplomatic recognition with Taiwan. As part of its 'dollar diplomacy', the Chinese government granted concessional loans and gifts to persuade countries that still held diplomatic relations with Taiwan, like Grenada and Saint Lucia, to switch their allegiance. Saint Lucia switched back its ties to Taiwan in 2007, much to the chagrin of Beijing. A number of Chinese construction firms landed in the region to build stadiums for the 2007 Cricket World Cup. These projects could still be considered part of China's 'dollar diplomacy', but they also marked the start of a second period in the relations. This period coincided with a general increase in Chinese outward investment throughout the world at the height of the 'Go Out' strategy, when a large number of Chinese companies internationalized in search of markets, technology, and resources (Gonzalez-Vicente 2011). In the case of the Caribbean, a region with small markets that are heavily dependent on foreign technology, commodities were the main pull factor. Attracted by the availability of natural resources, a number of Chinese companies came to the region. They invested, for example, in Trinidad and Tobago's oil sector in 2009, in Jamaica's sugar industry in 2010, and in Guyana's bauxite mining in 2012.

These trends continued in the third period of the relationship. However, this third period stands out for the way in which the BRI has financed a large number of infrastructural projects since 2013. Some of these projects are linked to traditional sectors such as tourism (e.g. resorts and hotels in the Bahamas and Barbados). Others have targeted the expansion of transportation infrastructure (e.g. Antigua, Bahamas, Guyana, Jamaica), the development of government buildings (e.g. Antigua, Trinidad and Tobago), the erection of convention centres (e.g. Antigua, Guyana, Jamaica, Trinidad), or more recently plans to develop industrial parks (e.g. Antigua, Jamaica, and Trinidad). Typically, infrastructure works are financed by Chinese policy banks such as the Export-Import Bank of China and the China Development Bank. These have given loans totalling over US $\$ 6.6$ billion in the broad Caribbean region, with Trinidad and Tobago (US $\$ 2.7$ billion) and Jamaica (US\$2.1 billion) standing out as the largest loan recipients (Gallagher \& Myers 2020). ${ }^{3}$

The investment strategies behind these various projects involve both geopolitical, developmentalist, and market rationales. To unpack these strategies, it is useful to first consider the different actors involved and then to consider the types of investment. Larger actors, such as the Chinese Ministry of Foreign 
Affairs and Ministry of Commerce, as well as China's policy banks and a few major state-owned enterprises, decide their investment strategies based on both economic and political considerations. As discussed above, a great geopolitical driver of China's relations with the Caribbean is the One-China policy. Through diplomatic manoeuvring and economic incentives, Beijing aims to ensure that those Caribbean countries that do not recognize the PRC (Belize, Haiti, Saint Kitts and Nevis, Saint Lucia, and Saint Vincent and the Grenadines) switch their allegiance. Two developmentalist considerations - intertwining political and economic goals - are also relevant. First, Chinese policy banks have actively subsidized the internationalization of Chinese companies since the deployment of the 'Go Out' strategy in order to increase the competitiveness of Chinese firms. With the launch of the BRI, these banks have also extended loans to regional governments in order to create new markets for Chinese construction firms that are currently facing a crisis of overaccumulation within the Chinese market (Jones \& Zeng 2019). Second, a number of major Chinese state-owned firms in commodity sectors understand resource procurement as both a market imperative and a state goal in relation to the use value of strategic resources such as bauxite in the Chinese economy ( $\mathrm{Lu} 2020)$. Finally, other Chinese state-owned and private firms in sectors such as construction see their role as eminently market-driven, and their 'logics of accumulation' are in this sense quite similar to those of global private capital (Lee 2017).

A second way of unpacking the transformative potential of Chinese investments in the region is by analysing their distinct impacts and the 'mechanisms of accumulation' required to set them in motion (Gonzalez-Vicente 2020). From this perspective, we can distinguish three types of investment (Gonzalez-Vicente \& Montoute 2020). First, we encounter investments that have a cumulative impact on regional development trends. These involve projects in sectors such as tourism or consolidated industries that export natural resources and so require little transformative activity and merely add to existing trends. Secondly, we have a number of Chinese companies that have ventured into sunset industries across the Caribbean, such as bauxite refining and sugar in Jamaica. The reasons why companies like the Jiuquan Iron and Steel Company (JISCO) in Jamaica can invest in sectors deemed unproductive by other transnational companies include their access to cheap credit from Chinese policy banks and the logics of accumulation described above that allow them to see some natural resources not just from the perspective of exchange value but from that of use value. Other reasons are that they have a different time logic as they are not tied by the immediate pressures to generate shareholder value, as well as their capacity to cut labour costs with the use of Chinese workers who are paid lower wages and work longer hours. 
Third, the quest for markets for Chinese construction firms that drives the BRI has introduced an innovative 'mechanism of accumulation' in the region (Gonzalez-Vicente 2020). China's 'state-coordinated investment partnerships' combine the various business and political rationales described above (Gonzalez-Vicente 2019). These arrangements involve the diplomatic branches of the Chinese government that negotiate with their local counterparts, policy banks that extend credits to host countries, a Chinese state-owned construction company that gets paid to complete the project, and sometimes a second company that will manage the project or circulate the resources used to pay for it. Crucially, these arrangements allow host governments to pay for the projects with a variety of arrangements. They might pay for a project, for example, with the future production of a resource or with concessions of land. Former Jamaican Prime Minister Bruce Golding explained how this has allowed heavily indebted economies to undertake necessary infrastructural works without increasing their debt burden or needing to agree to onerous macroeconomic conditionalities (Golding 2018). In this way, the arrival of Chinese investors in the Caribbean has created room for regional leaders to triangulate between economic partners, expanding investment despite the high debt burdens of many regional economies.

However, Chinese investments have also been the subject of critique. Scholars, the media, opposition politicians and a number of civil society actors have raised questions about the low levels of transparency in Chinese negotiations and the mounting debts that Caribbean economies now face after taking numerous Chinese loans. They have also raised concerns about poor labour standards, incomplete or low-quality projects, environmental impacts, and the prospects for broad socio-economic development on the back of an infrastructure-focused blueprint. The issue of low transparency has been a matter of concern throughout the Caribbean, as the type of government-to-government agreements promoted by Chinese policy banks entails high degrees of secrecy, sidelines debates on the need for BRI projects in the first place, prevents civil society scrutiny, and puts the procurement process under the control of a foreign entity (Raymond 2014). Piling debts are also a thorny issue in a region that has been held back by debt repayments for decades. A crucial question here is whether new investments in infrastructure can act as multipliers and generate enough economic activity to make up for their costs and interest rates.

When it comes to labour standards, two issues stand out. On the one hand, some Chinese companies in the region have ignored previous labour agreements and customs that, although not protected by law, had come to be expected. This has been the case in places like Jamaica, which I 
shall discuss in more detail below. On the other hand, the large numbers of Chinese workers that have been brought in to complete projects have limited the number of jobs available for locals, while also helping Chinese contractors to bypass local customs and regulations on wages and working conditions.

Delays and problems in the construction of projects are not unique to Chinese contractors, but those incurred by Chinese companies stand out due to the sheer size and relevance of some of these infrastructural endeavours. For example, in 2016 the project to build the Baha Mar resort in the Bahamas, the largest in the Caribbean, needed to file for bankruptcy after years of delays and problems with 'shoddy construction work' (Cohen 2016). The project had received a US\$2.5 billion loan from the Export-Import Bank of China, and had China State Construction Engineering as its main contractor. With a final cost of over US $\$ 3.5$ billion, the project would eventually be acquired and resurrected by Hong Kong's Chow Tai Fook Enterprises, but the case still features prominently in many debates about the reliability of Chinese projects in the region.

Questions have also been raised about the environmental impacts of Chinese projects. Despite a number of controversies, there is no data to indicate that the environmental standards of Chinese companies are lower than those of other local or transnational firms in the region. However, because they focus on the development of infrastructure and on the exploitation of natural resources, the environmental footprint of BRI activities in the Caribbean is inevitably a matter of contention. In the broader perspective of regional development, it is also not yet clear how much socio-economic progress can derive from large infrastructural works. In other words, it is not clear how much the lives of average Caribbean citizens can improve on the basis of the BRI's infrastructural blueprint for development.

In order to examine these issues further, the following two sections analyse the deployment of the BRI in Jamaica and Trinidad and Tobago, the two largest economies in CARICOM. The two cases contain a variety of projects and as such they cannot be seen as an ideal type of any singular trend. There are overlapping trends in both countries that can also be observed in other regional economies. However, the case of Jamaica offers the opportunity to study in some detail the prospects of Chinese investments in productive sectors and logistics. Meanwhile, the Trinidad and Tobago case contains more examples of infrastructural projects associated with the hospitality industry, as well as the culture and sports sectors. In both cases, I focus on the trajectories of Chinese investments and the ways in which these are shaped by different types of local agency. The question of agency 
has been extensively debated and documented in the literature on China's overseas investments (Levy 2015). Scholarship has typically focused on identifying the actors that mould China's global footprint, be these Chinese business and state actors or host governments and civil societies. Going beyond this, I contend that in analysing the forays of Chinese investments in the Caribbean it is also necessary to appraise the agency of other actors. We need to examine, for example, the role of actors such as the IMF and others that through decades have played a role in delineating the policy alternatives available to Caribbean states and crafting the political economic environment in which Chinese companies now operate. As such, agency is seen here as the capacity to shape developmental trajectories vis-à-vis contextual constraints, and in negotiation and conflict with the ideas and interests of other relevant actors.

\section{Jamaica: Not an Easy Road}

Perhaps more than any other in the Caribbean, the relationship between China and Jamaica has been shaped, and continues to be shaped, by the neoliberal era that preceded it. For decades, Jamaica has been crippled by one of the highest debts per capita relative to GDP and sluggish economic growth. The IMF's structural adjustment plans did little to lift the island out of its situation of underdevelopment. Instead, the privileging of debt repayment over other social priorities has been identified as a main cause of the low economic growth, high unemployment rates, inequality, and vulnerability that Jamaica has suffered (Johnston 2013). Therefore, when Chinese companies came to the island at the beginning of the twenty-first century, Jamaica was a country desperate for new sources of funding to address a number of socio-economic maladies. However, a decade after deepening the relationship with China, Jamaica has not overcome its developmental impasse. While Chinese finance and investments have reshaped the country's international outlook, many of the problems developed in Jamaica's recent history remain, and new challenges have emerged in the Sino-Jamaican link. To understand these trends, I will first assess BRI projects in Jamaica by the yardstick of their own business success, asking whether they have achieved what they originally intended to. After that, I will review the limitations and promises that such projects carry from a critical development perspective. Then I will reflect more broadly on the geopolitical and developmental trajectory of Jamaica under Chinese influence. 
From the perspective of business success, the BRI in Jamaica offers a mixed track record. First, there have been a number of projects that have not managed to lift off. An early investment of US\$26o million by China's Pan-Caribbean Sugar Company encountered a series of social and cultural barriers that hindered its bid to revitalize the sugar sector. Productivity remains low and company managers have floated the idea of closing down in the face of competition from countries like Thailand (Jamaica Gleaner 2017). Plans by the China Harbour Engineering Company (CHEC) to build a transshipment terminal in Goat Island were aborted on account of civil society pressures and concerns over environmental impacts (Jamaica Observer 2016). This remains one of the few cases of successful societal organization against a Chinese project in the Caribbean. As such, it should not be seen as a failure in itself, but an exemplary case of how civil society can mobilize to shape developmental trajectories.

Second, there have been a number of projects that have been completed but remain underutilized. One of these is the North-South Highway, which is a centrepiece of China's infrastructural campaign in Jamaica. The 'Beijing Highway', as the project is sometimes known, was successfully completed by CHEC in 2016 with a US $\$ 457$ million loan by the China Development Bank. However, the highway is operating at limited capacity, as the toll prices charged by CHEC are unaffordable for a majority of locals (Foxcroft 2019). The utility and economic viability of other projects has also been questioned. For example, the Montego Bay Convention Centre, which was built with a US $\$ 45$ million concessional loan from the Export-Import Bank of China (Eximbank), is said to remain underutilized and has incurred significant losses after its construction (Radio Jamaica News 2012). The case of JISCO's investment in the Alumina Partners of Jamaica |(Alpart), which operates a bauxite refinery, is more ambiguous. JISCO was able to reopen the plant, generate employment, and significantly revitalize economic activity in the Saint Elizabeth area of the island. However, the refinery operations have been suspended for a period of at least two years since September 2019, when the company presented the government with plans to expand and modernize the plant. This has also put on hold plans to develop an industrial park in the surrounding area. JISCO's business success will therefore depend on whether the modernization of the plant allows it to cope with the issues of low productivity encountered by previous investors, particularly against the backdrop of low aluminium prices (Aluminium Insider 2019). All in all, from a business perspective, Chinese firms have had relative success in the delivery of infrastructure. However, they have encountered problems when trying to put this infrastructure into use and when attempting to revitalize natural resources industries. 
If we go beyond measurement of the projects according to their stated goals, assessing them instead on their broad developmental impacts, a different type of question needs to be asked. Regarding labour, Chinese companies have generated a significant number of jobs, particularly in the construction sector. While this has helped to address problems of unemployment and exclusion, the quality of Chinese jobs has helped to perpetuate trends of exploitation. This is clear in JISCO's operations in Saint Elizabeth. The Nain area of Saint Elizabeth had lain semi-abandoned for almost a decade until operations restarted in the plant under Chinese ownership. JISCO rehired 700 local workers to operate the plant. However, the plan to make the refinery productive included significant cuts in labour costs. This involved the casualization of local workers, who unlike in the past are now hired with flexible short-term contracts and salaries that are lower than those received in 2009. A significant contingent of Chinese workers joined the operation. Chinese workers live in compounds next to the refinery, receive lower salaries, and are possibly the main targets of exploitative labour practices.

A similar case is found on Chinese construction sites. Chinese infrastructural projects often require the creation of 'spaces of exception' that allow the transfer of Chinese labour practices into Jamaica (Gonzalez-Vicente 2019). For example, Chinese workers are often paid Chinese salaries into Chinese accounts, bypassing local labour regulations. Meanwhile, Chinese companies benefit from levies on equipment duties and other taxes. Jamaican workers have also complained about wages that are lower than those provided by other local contractors. However, not all labour problems can be traced back to a uniquely Chinese way of running business. It is indeed the case that Chinese companies do not follow the salary scales negotiated between the Incorporated Masterbuilders Association of Jamaica and trade unions in the sector. Yet, in choosing to ignore these agreements, Chinese contractors are adhering to IMF-promoted flexible labour laws, which impose no sector-specific minimum wages but a cross-sectoral minimum wage of about US $\$ 5^{\circ}$ per week. As indicated above, the impacts of the BRI on labour issues in Jamaica have very much been shaped by preceding decades of neoliberal orthodoxy.

More broadly, Chinese investments have also generated debates about environmental sustainability, local agency and participation, transparency, and the ultimate developmental potential of infrastructural works. JISCO's activities have been a key concern for environmentalists in Jamaica. Local residents in the Nain area have been affected by dust blown from the refinery's disposal area, although long-term observers such as Richard 
Bernal have noted that 'the residue from bauxite plants [has] been here since they were established 50 years ago by Canadian and American firms' (Foxcroft 2019). From an environmental perspective, Chinese firms in Jamaica have mostly had a cumulative impact and do not stand out as the main drivers of environmental damage. However, when it comes to issues of local agency, participation, and transparency, Chinese investors do stand out for their poor performance. Despite allowing the Jamaican government to overcome its dependence on Western institutions and investors, the government-to-government, closed-door deals produced by the BRI have cemented a top-down, elite-driven approach to development. The agency and leverage devolved to the Jamaican central government has been used in ways that undermine participatory development. As a consequence, the adequacy of BRI infrastructural projects in Jamaica has not been properly debated (Gonzalez-Vicente \& Montoute 2020). Central government elites have rushed to sign agreements with China, pressed by the urgency to create jobs and generate economic activity. Few of these projects seem to have significantly improved the lives of targeted beneficiaries. Chinese infrastructure has also not acted as a multiplier that has been able to generate economic activity beyond the construction sector itself.

All in all, the BRI has not offered Jamaica an easy road out of its decades-long developmental impasse. Chinese finance and investment have boosted economic activity on the island and generated much-needed jobs in the construction and natural resources sectors. Yet these jobs are often precarious, and despite that fact that Jamaica's debt to China has increased significantly, the country has not significantly addressed any of its structural and socio-economic challenges. From a geopolitical perspective, there is little evidence to suggest that Chinese companies act as Beijing's political envoys. Instead, what we observe is substantial Chinese state support for the expansion of Chinese capital, in the form of soft loans and diplomatic efforts. This confirms the view that the BRI is driven by a crisis of over-accumulation in China and implemented by both state agencies that pursue a developmentalist goal and businesses that respond to a commercial mandate (Gonzalez-Vicente 2019; Jones \& Zeng 2019).

However, despite the concerns expressed by US diplomats, Jamaica's growing relationship with China has not drawn it away from its traditional allies. For example, Prime Minister Andrew Holness recently joined other Caribbean leaders at Donald Trump's private club in Palm Beach to discuss a potential change of regime in Venezuela - a move that the Chinese government would be unlikely to endorse. More recently, in the midst of the coronavirus crisis, Jamaica once again applied for IMF loans. Finally, a 
somewhat paradoxical result of the growing relations between Jamaica and China has been a relative decline in China's soft power. On the one hand, political elites within the country have been very open to the immediate economic gains - and subsequent political capital - granted by an increased engagement with Chinese banks and companies. On the other, however, the very visible growth of Chinese activity in Jamaica has triggered an anti-China discourse that unfortunately has also at times translated into xenophobic attitudes by the general public and some media. If China's growing economic might in Jamaica does not result in improved life standards for a majority of the country's population, it is possible that increased engagement will lead to resistance rather than the embrace of a new hegemony.

\section{Trinidad and Tobago: Ready for the Road?}

Unlike Jamaica, Trinidad and Tobago is a resource rich, high-income economy that ranks high in the UN's human development index (UNDP 2019). However, the country's dependence on its oil and gas sectors has been traditionally associated with high levels of inequality, unemployment, problems diversifying the economic basis, and recurring vulnerability and poverty (Auty 2017). In the case of Jamaica it could be said that the BRI has a mixed track record on a project-by-project basis and has proved overall unable to lift the country from its developmental impasse. Meanwhile, in Trinidad and Tobago what we observe is a mismatch between what the BRI has offered to date and what the country would need in order to tackle its various developmental shortcomings. BRI funding has been directed at the construction of a number of buildings scattered throughout Trinidad. These have great visual impact but have not truly had a clear developmental function, whether from an economic or a broader social perspective. The recent plans to use Chinese capital to develop the Phoenix Park Industrial Estate in southern Trinidad seek to address some of the shortcomings of earlier Chinese investments. However, these plans have not yet come to fruition and there are precedents that suggest a cautious appraisal of the Phoenix Park's developmental prospects. In order to further understand the relationship between China and Trinidad and Tobago, I will first evaluate the success of Chinese projects in delivering their intended outcomes. Then I will go on to reflect on whether these projects tackle the needs of the twin-island state.

The assessment of Chinese business success in Trinidad might begin by looking at a series of natural resources-focused investments that have 
contributed to perpetuating the role of the country as an exporter of natural resources. One of these was a US $\$ 850$ million investment by the China Investment Corporation to acquire a 10\% share in Atlantic LNG in 2011. Another was an agreement in 2018 to export asphalt from Trinidad's Pitch Lake to pave the runways of the Beijing Daxing International Airport (Ellis 2019). These are investments in sectors in which Trinidad has been traditionally competitive. As such they have run relatively smoothly. A second group of investments are those in the construction sector which successfully delivered what they had promised. Here we can include the construction of the National Cycling Velodrome, the National Aquatic Centre, the National Tennis Centre, the Prime Minister's Official Residence (built with an interestfree loan) (Stallings 2017: 81), the Port of Spain Waterfront, the Ministry of Education Tower, and the restoration of the Knowsley Building. All of these projects were completed by the Shanghai Construction Group (SCG), which is without a doubt the most active Chinese company in Trinidad.

SCG has, however, encountered challenges in some of its other projects. For example, the Couva Children's Hospital remains emblematic of the BRI's emphasis on physical infrastructure rather than content. The hospital needed to be repurposed as a 'multi-training facility' after encountering staffing problems and other shortcomings related to the project's design (Khan 2020). Some other announced projects have failed to come to fruition. These include, for example, a contract awarded to the China Gezhouba Group (CGG) to build 5000 'low-cost' apartments. Trinidad's cabinet revoked the contract after media and activists took issue with the costs of the project, with estimates putting the total cost at US\$80o million $-30 \%$ above the rates usually charged by local contractors (Raymond 2019). Commentators also lamented the lack of transparency in the negotiations and the fact the agreement privileged a foreign investor over local contractors, with tax exemptions, an agreement to grant 600 working permits for Chinese workers, and full financial guarantees on the payment to CGG (Wilson 2019). Another interesting case is the scrapping of plans to develop a five-star Sandals resort in Tobago. The project would have involved China's HNA Group, but was dropped by Sandals under allegations that the conflicts between Trinidad and Tobago's two main political parties contributed to a discouraging business environment (Bridglal 2019).

These last two cases shed light onto a pattern that has emerged around Chinese investments in Trinidad. The mechanisms of accumulation advanced by the BRI have allowed the two main parties to engage in a battle to surpass each other's infrastructural legacy. The NAPA-SAPA saga illustrates this trend quite well. The National Academy for the Performing 
Figure 7.1 Interior of Trinidad's National Academy for the Performing Arts during an event in January 2020, with the Queen's Park Savannah and the hills of Port of Spain in the background

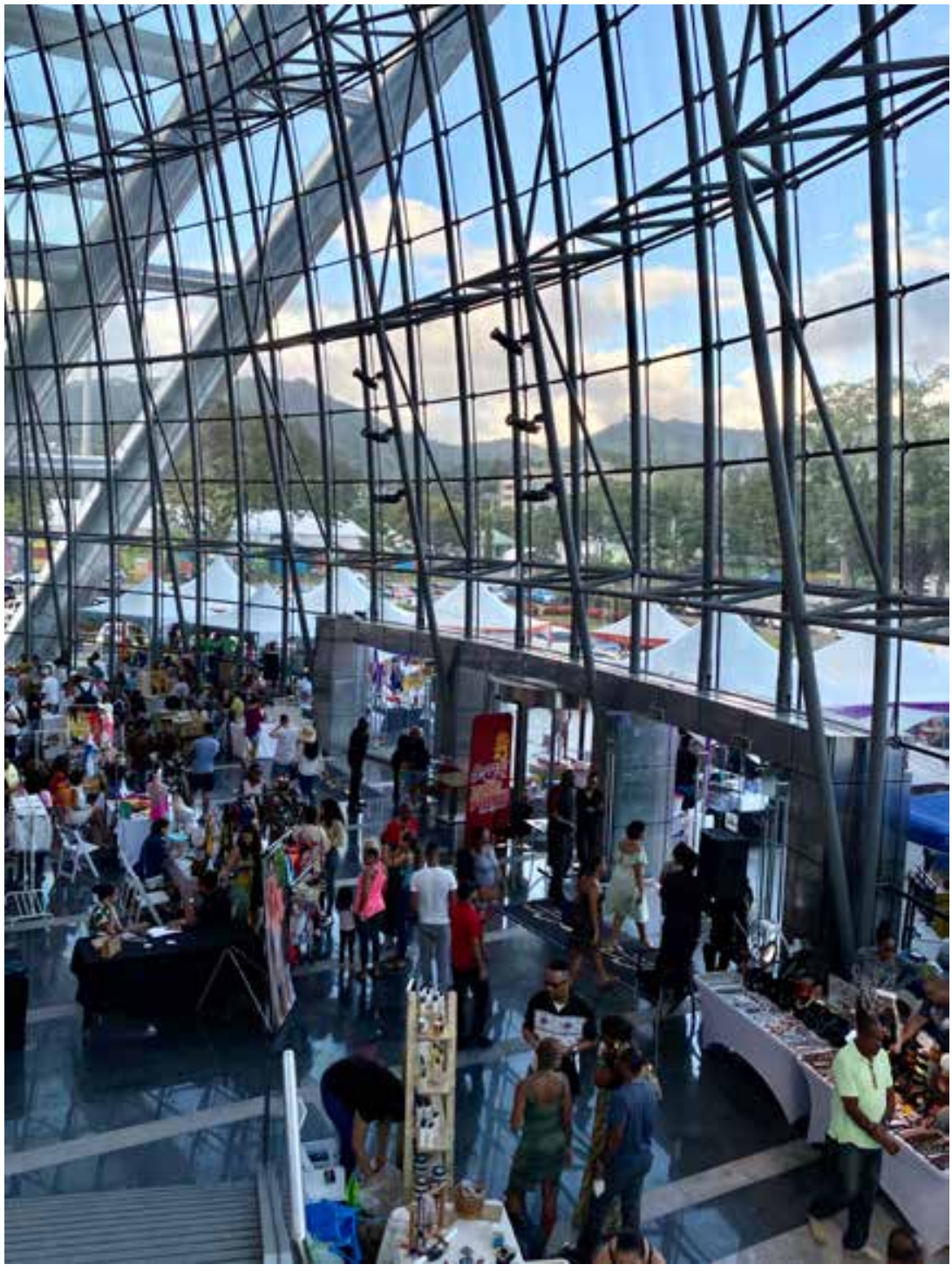

Source: Author

Arts (NAPA), an imposing structure adjacent to Port of Spain's Queen's Park Savannah, was commissioned by the Patrick Manning government (People's National Movement, PNM) and completed by the SCG in 2009. The 
United National Congress (UNC) had been a vocal critic of the project, which incurred costs overruns and involved a potential case of embezzlement by the former chairman of the Urban Development Corporation of Trinidad and Tobago (Oosterveld et al. 2018). Soon after reaching power in 2010, the Kamla Persad-Bissessar administration (UNC) closed down the NAPA, claiming problems with the original design. In the meantime, the UNC inaugurated the Southern Academy for the Performing Arts (SAPA), an equally imposing structure in the city of San Fernando. San Fernando lies close to the central plains of Trinidad, where UNC votes have been concentrated since the 1960 s (Premdas 2004). SAPA was also built by the SCG, and as had been the case with NAPA, it was a top-down project developed without properly consulting local artists (Newsday 2010). NAPA would reopen in 2015, once the PNM returned to power, although only after the building was repaired at a significant cost, with parts of the compound, such as a 53-room hotel, still underutilized.

Projects such as NAPA and SAPA indicate that Trinidad and Tobago has not made the best possible use of BRI financing, privileging legacy infrastructure over potentially meaningful projects. For example, Trinidad experiences serious traffic problems, with a deficient public transportation system and daily two-hour traffic jams to get in and out of Port of Spain. Yet the possibility of harnessing Chinese loans towards improvements in public transportation has not been discussed, despite Chinese companies' expertise in this area. The BRI has also done little to tackle perennial structural problems, such as lack of economic diversification and high unemployment rates. Following the shutdown of Petrotrin, one of the main employers in San Fernando, the government came to an agreement with the Beijing Construction and Engineering Group (BCEG) to develop the Phoenix Park Industrial Estate and a dry dock in La Brea for a cost of around US\$60o million (Ellis 2019). If these plans materialize, the park will host ten Chinese firms in sectors such as air conditioning, food processing, building materials, and communication equipment, and could generate up to 4,500 jobs (News.gov.tt 2018). However, despite a number of ceremonies to announce the project, construction work has been virtually halted. In interviews conducted for this chapter, local experts speculated that the government's urgency to announce the plan had more to do with the August 2020 general election than with actual progress in planning the project, particularly given the urge to appease the population in southern Trinidad following the shutdown of Petrotrin.

All in all, the BRI has not truly addressed Trinidad and Tobago's developmental bottlenecks, while the country's debt to China has risen after 
receiving loans for US\$2.7 billion. The responsibility for many of the missed opportunities lies with the local government and its inability to direct Chinese finance towards meaningful projects. This highlights the relevance of local agency. However, the BRI, as an infrastructure-focused campaign, also has limited potential to address Trinidad's needs for diversification and for the creation of long-term sources of well-paid qualified jobs. The plans to develop the Phoenix Park could signal that Trinidad and Tobago and China are moving along the learning curve in their relationship, if the project delivers the 4,500 jobs promised. However, the precedents are not encouraging. It also remains unclear how Trinidad and Tobago will boost its competitiveness in sectors not related to or subsidized by the country's energy sector.

\section{Conclusion}

The Belt and Road Initiative has generated a new wave of economic activity in the Caribbean, a region that had experienced an arduous cycle of debt and sluggish growth in the decades building up to its engagement with China. Some Chinese investments have gone into traditional sectors, and as such have had a cumulative impact. Others have helped to at least temporarily revitalize some sunset industries. However, the majority of Chinese investments have gone into the region's infrastructural sectors, and have been facilitated by loans provided by China's policy banks at a market rate. Overall, the projects that have seen the most success are those that have built into the region's already existing strengths in the tourism industry and some natural resources sectors. Other infrastructural projects have become white elephants, in part due to a tendency by some regional governments to endorse projects that generate immediate economic activity and short-term jobs without seriously considering their long-term prospects vis-à-vis rising debt.

Importantly, Chinese finance has allowed regional economies to seek sources of financing that do not impose the type of neoliberal conditionalities promoted by institutions such as the IMF or the World Bank. While this could in principle suggest a potentially unorthodox development partnership, this chapter's findings suggest that the BRI instead encourages an elitist and business-centric developmental rationale that dovetails with other predominant socio-economic trends in the region. The BRI eschews participatory approaches and relies on opaque government-to-government agreements, which has prevented Caribbean civil societies from playing 
an active role in deciding what are the regional priorities or in designing projects that take into consideration the needs of communities. Thereby, despite its distinct format, the BRI in the Caribbean remains a campaign to open markets for Chinese investors, and its goals are hence remarkably similar to those of other transnational investors and Western-based institutions. As such, the BRI has not been a panacea for the Caribbean and has instead helped to perpetuate the structural constraints that have historically characterized the region's developmental trajectory.

\section{References}

Aluminium Insider (2019, August 18). 'Falling Aluminium Prices May Make Life Difficult for Jamaican Bauxite Operations: PM Paulwell'. Retrieved 30 April 2020 from https://aluminiuminsider.com/falling-aluminium-prices-may-make-lifedifficult-for-jamaican-bauxite-operations-pm-paulwell/.

Auty, Richard M. (2017). 'Natural Resources and Small Island Economies: Mauritius and Trinidad and Tobago'.Journal of Development Studies, 53(2), 264-277.

Beckford, George L. (1972). Persistent Poverty: Underdevelopment in Plantation Economies of the Third World. New York: Oxford University.

Bernal, Richard (2000). 'Globalisation and Small Developing Countries: The Imperatives of Repositioning'. In Dennis Benn \& Kenneth Hall (eds.), Globalisation: A Calculus of Inequality Perspectives from the South (pp. 88-127). Kingston: Ian Randall Publishers.

Bissessar, Anne M. \& La Guerre, John G. (2013). Trinidad and Tobago and Guyana: Race and Politics in Two Plural Societies. Lanham: Lexington Books.

Black, Stephanie, dir. (2001). Life and Debt. New Yorker Films.

Bridglal, Carla (2019, January 17). 'PM: We Chased Sandals Away'. Newsday. Retrieved 30 April 2020 from https://newsday.co.tt/2019/01/17/pm-we-chased-sandals-away/. CDB (2016). The Changing Nature of Poverty and Inequality in the Caribbean: New Issues, New Solutions. Barbados: Caribbean Development Bank.

Clarke, Nigel (2019, February 19). 'Lessons from Jamaica for Small Countries with Big Debts'. Financial Times. Retrieved 9 May 2020 from https://www.ft.com/ content/0487ofa8-2e12-11e9-8od2-7b637agerba1.

Cohen, Muhammad (2016, December 14). 'How China Rescued - Then Ruined - The Caribbean's Largest Resort Project'. Forbes. Retrieved 9 May 2020 from https:// www.forbes.com/sites/muhammadcohen/2016/12/14/how-china-rescued-thenruined-the-caribbeans-largest-resort-project/\#4a66fded3edb.

Dearden, Nick (2013, April 16). 'Jamaica's Decades of Debt Are Damaging Its Future'. The Guardian. Retrieved 4 May 2020 from https://www.theguardian. 
com/global-development/poverty-matters/2013/apr/16/jamaica-decades-debtdamaging-future.

Donovan, Elise (2018, March 29). 'Going for Global Growth: Why China Chooses the BVI'. BVI House Asia. Retrieved 5 May 2020 from http://www.bvihouseasia. com.hk/news/going-for-global-growth-why-china-chooses-the-bvi.

ECLAC (2000, January 31). 'The Caribbean in the Decade of the gos: Summary'. LC/CAR/G.6oo. Port of Spain: UN Economic Commission for Latin America and the Caribbean.

ECLAC (2018, June). The Caribbean Outlook. Santiago: UN Economic Commission for Latin America and the Caribbean.

Ellis, Evan (2019, March 26). 'China's Engagement with Trinidad and Tobago'. Global Americans. Retrieved 5 May 2020 from https://theglobalamericans.org/2019/03/ chinas-engagement-with-trinidad-and-tobago/.

Foxcroft, Tiffany (2019, November 28). 'Jamaica Has China to Thank for Much-Needed Infrastructure - But Some Locals Say It Has Come at a Price'. CBC News. Retrieved 5 May 2020 from https://www.cbc.ca/news/world/ china-power-belt-and-road-caribbean-jamaica-1.5374967.

Gallagher, Kevin P. \& Myers, Margaret (2020). 'China-Latin America Finance Database'. Washington, DC: Inter-American Dialogue.

Girvan, Norman (2009). 'Plantation Economy in an Age of Globalization'. In Lloyd Best \& Kari Levitt Polanyi (eds.), Essays on the Theory ofPlantation Economy: A Historical and Institutional Approach to Caribbean Economic Development (pp. xvii-xxii). Jamaica, Barbados and Trinidad and Tobago: The University of the West Indies Press.

Girvan, Norman (2012, August 22). '50 Years of In-dependence in Jamaica: Reflections'. Lecture presented at the SALISES 50-50 Conference Critical Reflections in a Time of Uncertainty, Kingston, Jamaica.

Golding, Bruce (2018, April 1). 'North-South Highway Paternity'.Jamaica Observer. Retrieved 28 April 2020 from http://www.jamaicaobserver.com/parliament/ north-south-highway-paternity_129364\&template=MobileArticle.

Gonzalez-Vicente, Ruben (2011). 'The Internationalization of the Chinese State'. Political Geography, 30(7), 402-411.

Gonzalez-Vicente, Ruben (2019). 'Make Development Great Again? Accumulation Regimes, Spaces of Sovereign Exception and the Elite Development Paradigm of China's Belt and Road Initiative'. Business and Politics, 21(4), 487-513.

Gonzalez-Vicente, Ruben (2020). 'Varieties of Capital and Predistribution: The Foundations of Chinese Infrastructural Investment in the Caribbean'. Made in China Journal, 5(1), 164-168.

Gonzalez-Vicente, Ruben \& Montoute, Annita (2020). 'A Caribbean Perspective on China-Caribbean Relations: Global IR, Dependency and the Postcolonial Condition'. Third World Quarterly (Online First). 
Grenade, Wendy (2011, September). 'Regionalism and Sub-regionalism in the Caribbean: Challenges and Prospects - Any Insights from Europe?' Jean Monnet/ Robert Schuman Paper Series, vol. 11, no. 4.

Gumbs, Frank (1981). 'Agriculture in the Wider Caribbean'. Ambio, 10(6), 335-339. Jamaica Gleaner (2017, November 21). 'Chinese Hit Hard by Realities in Local Sugar Industry'. Retrieved 6 May 2020 from http://jamaica-gleaner.com/article/leadstories/20171121/chinese-hit-hard-realities-local-sugar-industry\#.XVxzYcbz2Hw. email.

Jamaica Observer (2016, September 28). 'Environmentalists Welcome Scrapping of Goat Island Project'. Jamaica Observer. Retrieved 6 May 2020 from http://www.jamaicaobserver.com/news/Environmentalists-welcome-scrapping-of--Goat-Island-project.

Johnston, Jake (2013, June). 'The Multilateral Debt Trap in Jamaica'. Issue Brief. Center for Economic and Policy Research (CEPR). Retrieved 6 May 2020 from http://cepr.net/documents/publications/jamaica-debt-2013-06.pdf.

Jones, Lee \& Zeng, Jinghan (2019). 'Understanding China's “Belt and Road Initiative": Beyond "Grand Strategy" to a State Transformation Analysis'. Third World Quarterly, 40(8), 1415-1439.

Khan, Rishard (2020, February 29). 'Lee Pleased with COVID-19 Plans for Couva Hospital'. Trinidad and Tobago Guardian. Retrieved 6 May 2020 from http:// www.guardian.co.tt/news/lee-pleased-with-covid19-plans-for-couva-hospital6.2.1067874.1e42e264fi.

Kirton, Claremont \& Ferguson, James (1992). Jamaica Debt and Poverty. Oxford: Oxfam.

Lee, Ching Kwan (2017). The Specter of Global China: Politics, Labor and Foreign Investment in Africa. Chicago: University of Chicago Press.

Levitt, Kari P. (2009). 'In Search of Model IV'. In Lloyd Best \& Kari P. Levitt (eds.), Essays on the Theory of Plantation Economy: A Historical and Institutional Approach to Caribbean Economic Development (pp. 189-196). Jamaica, Barbados and Trinidad and Tobago: The University of the West Indies Press.

Levy, Katja (2015). 'Introduction: China and Latin America - Bringing the Actor Back In'. Journal of Chinese Political Science, 20 (3), 221-225.

Look Lai, Walton (1998). The Chinese in the West Indies 1806-1995. Kingston: The Press University of the West Indies.

Lu, Juliet (2020). 'Strategic Resources and Chinese State Capital'. Made in China Journal, 5(1), 154-159.

Lundy, Patricia (1999). Debt and Adjustment: Social and Environmental Consequences in Jamaica. Aldershot: Ashgate.

Minto, Jevon (2019). 'Examining the Lending Practices of Chinese Policy Banks in the Caribbean (2000-2018)'. In Enrique Dussel Peters (ed.), China's Financing 
in Latin America and the Caribbean (pp. 153-176). México, D.F.: Universidad Nacional Autónoma de México.

Newsday (2010, March 21). 'Stop the South Academy'. Newsday. Retrieved 6 May 2020 from https://archives.newsday.co.tt/2010/03/26/stop-the-south-academy/.

News.gov.tt (2018). 'MOU between eTeck and BCEG for Development of Phoenix Park Industrial Estate'. News.gov.tt [Government of the Republic of Trinidad and Tobago]. Retrieved 6 May 2020 from http://news.gov.tt/content/moubetween-eteck-and-bceg-development-phoenix-park-industrial-estate\#. XqhdhxMzZhA.

Oosterveld, Willem, Wilms, Eric \& Kertysova, Katarina (2018). The Belt and Road Initiative Looks East: Political Implications of China's Economic Forays in the Caribbean and the South Pacific. The Hague: The Hague Centre for Strategic Studies.

Padilla-Pérez, Ramón \& Hernández, René A. (2010). 'Upgrading and Competitiveness within the Export Manufacturing Industry in Central America, Mexico, and the Dominican Republic'. Latin American Business Review, 11(1), 19-44.

Pantin, Dennis A. (1996). The Challenge of Youth Unemployment in the Caribbean. The Role of Youth Employment Training Programmes. Port of Spain:International Labour Organization Caribbean Office.

Payne, Anthony \& Sutton, Paul (2007). 'Repositioning the Caribbean within Globalisation'. Caribbean Paper no. 1. Centre for International Governance Innovation. Retrieved 26 October 2020 from https://www.cigionline.org/sites/ default/files/1._repositioning_the_caribbean_within_globalisation.pdf.

Premdas, Ralph R. (2004). 'Elections, Identity and Ethnic Conflict in the Caribbean: The Trinidad Case'. Pouvoirs dans la Caraïbe, 14, 17-61.

Radio Jamaica News (2012, October 10). 'UDC under the Gun, Suffers Loss of \$500 Million'. Radio Jamaica News. Retrieved 6 May 2020 from http://rjrnewsonline. com/local/udc-under-the-gun-suffers-loss-of-500-million.

Raymond, Afra (2014, April 30). 'G2G Policy'. Afraraymond.net. Retrieved 9 May 2020 from https://afraraymond.net/2014/04/30/g2g-policy/.

Raymond, Afra (2019, September 4). 'Property Matters - In-Dependence?' Afraraymond.net. Retrieved 6 May 2020 from https://afraraymond.net/2019/o9/04/ property-matters-in-dependence/.

Robertson, Justin (2019). 'Global Financial Networks Confront Headwinds: China's Shifting Offshore Relationship with the British Virgin Islands'. Pacific Review, DOI: 10.1080/09512748.2019.1671893.

Stallings, Barbara (2017). 'Chinese Foreign Aid to Latin America: Trying to Win Friends and Influence People'. In Margaret Myers \& Carol Wise (eds.), The Political Economy of China-Latin America Relations in the New Millennium: Brave New World (pp. 69-91). New York: Routledge. 
Stone, Carl (1986). 'Prospects for Socialist Transformation: Reflections on Jamaica, Guyana and Grenada'. In George Beckford (ed.), A Caribbean Reader on Development (pp. 20-48). Kingston: Friedrich Ebert Stiftung.

UNDP (2019). Human Development Report. United Nations Development Programme. Retrieved 6 May 2020 from http://hdr.undp.org/en/content/ 2019-human-development-index-ranking.

Williams, Eric (1984). From Colombus to Castro: The History of the Caribbean. New York: Vintage Books.

Wilson, Anthony (2019, September 6). 'HDC Project Halted'. Trinidad Express. Retrieved 6 May 2020 from http://trinidadexpress.tto.newsmemory.com/? publink=obc61b661.

\section{About the Author}

Ruben GonZalez-ViCEnte is a Lecturer at Leiden University. His research interests include 'South-South' development cooperation, China's international relations (with a specific interest on China's engagement in Latin America and the Caribbean), the role of natural resources in processes of development, and the transformation of politics and international relations under late capitalism. His work has been published in journals such as Review of International Political Economy, Political Geography, Globalizations, the China Quarterly, and Latin American Politics and Society. He received his PhD from Cambridge in 2012 and worked as an Assistant Professor in the City University of Hong Kong between 2012 and 2016 before moving to Leiden. 